AUTHOR POST-PRINT OF MANUSCRIPT ACCEPTED FOR PUBLICATION IN AUSTRALIAN SOCIAL WORK (MAY 2020)

Title Page

The production and dissemination of Australian social work scholarship:

A citation analysis

Clare Tilbury $^{1}$, Christine Bigby $^{2}$, and Mark Hughes ${ }^{3}$

1. School of Human Services and Social Work, Griffith University, Logan campus QLD 4131, Australia.

2. Living with Disability Research Centre, School of Allied Health, La Trobe University, Bundoora VIC 3086, Australia.

3. School of Arts and Social Sciences, Southern Cross University, Locked Mail Bag 4, Coolangatta, QLD 4225, Australia.

Corresponding author:

Clare Tilbury

School of Human Services and Social Work

Griffith University, Logan campus

MEADOWBROOK Q 4131 AUSTRALIA

Email: c.tilbury@griffith.edu.au 


\title{
The Production and Dissemination of Australian Social Work Scholarship: \\ A Citation Analysis
}

\begin{abstract}
Understanding the scholarly impact of social work research can inform strategies to strengthen the profession's research foundations. This study examined research productivity and academic impact using h-indexes for a sample of 112 Australian social work researchers according to stage of career. Annual research output was calculated using Excellence in Research for Australia (ERA) data. The average h-index for all social work researchers in the sample was 6.39 (Scopus) and 12.5 (Google Scholar). Web of Science was not used due to the number of inaccurate researcher profiles. 139 publications received 100 or more citations, but there were many never-cited publications. A social work benchmark for number of publications is around 1.4 publications per year, depending upon stage of career and workload profile. Citation analysis can supplement peer review in evaluating research quality, but there are disciplinary differences in publication and citation practices, so it is useful to know where social work is positioned.
\end{abstract}

\section{Implications statement}

- Citation analysis is used to assess research productivity and quality alongside qualitative assessment, such as peer review

- It is imperative for researchers to check, correct, and claim Google Scholar, Scopus and Web of Science records, and to link these to their ORCID profile.

- A citation benchmark for social work would be in the range of h-index 3.2 for early career researchers to 15.8 for research-focused positions (Scopus) or h-index 6.1 to 25.0 (Google Scholar).

Key words: citation, metrics, quantitative, research assessment 


\section{The Production and Dissemination of Australian Social Work Scholarship:}

\section{A Citation Analysis}

Quality research is critical to inform policies, program design and implementation, and innovative practice in the human services. As a dominant profession in the field, social work research is vital to inform better responses to disadvantage, discrimination, and social exclusion. Understanding the scholarly contribution of social work research can inform strategies to strengthen the profession's research base (Tilbury, Hughes, Bigby, Fisher, \& Vogel, 2017). Notwithstanding the importance of traditional markers, such as peer review, there has been a shift to factoring in real-world impact and using metrics or quantitative data to assess research quality and productivity. As methods for measuring non-academic impact are in the early stage of development, the two main indicators of research productivity used by universities are grants awarded and academic publications. These are assessed qualitatively (e.g., with reference to funding source and journal reputation) and quantitatively (e.g., with reference to funding quantum and number of publications per annum). Increasingly, citation metrics are also being used. Having laboured to publish a journal article, book, or book chapter, most academics would like them to be read. It is even better if the reader finds them helpful to their thinking about research, policy development, or practice. Citations are one indicator that someone, usually another academic, has read your paper and found it to be useful (albeit not all citations are positive). Although non-citation rates vary by field, the proportion of never cited articles in the social sciences is estimated at one-third (Powell, 2016). Conversely, highly cited research can be influential in shaping future research, policy, and practice (Hodge, Lacasse, \& Benson, 2012).

There are different types of citation metrics. A citation is a quotation from, or reference to, a scholarly work-typically a book, book chapter, or journal article. Citations pertain to individual publications. In general terms, the relevance, quality, and originality of a 
publication determines how much it is cited. The $h$-index is a citation metric that pertains to authors, which is calculated from the number of citations received over time to an author's collected works and used to signify influence in a field of research (Lacasse, Hodge, \& Bean, 2011). The journal impact factor is a different type of citation metric that signifies the academic standing of a journal (rather than an author or article). The journal impact factor measures the number of citations received by all the papers published in a journal in the two years previous. They are used to categorise journals into quartiles and many universities encourage publication in "Q1" and "Q2" journals. Altmetrics is a term for alternative metrics that count social media shares, "likes", downloads, and public discussion, and many journal publishers encourage authors and journal editors to use social media platforms to disseminate their content. Altmetrics are still rudimentary and citations in non-academic outputs do not count in citation indexes, but they may become useful indicators of non-academic engagement (Staller, 2017). This paper is concerned with author-level scholarly citations that is, the h-index.

Citation metrics are increasingly used to evaluate the quality of academic publications, alongside the traditional method of peer review. Australian research assessment (via the Excellence in Research for Australia [ERA] exercise) uses a dual approach: the humanities and social sciences, including social work, are designated "peer review disciplines"; whereas the natural sciences, which more commonly use citation analysis to assess quality, are designated "citation disciplines". Nonetheless, all disciplines routinely draw upon citation metrics and other quantitative indicators (e.g., publication volume and grant quantum and type) to evaluate grant applications, promotions, and appointments. It is claimed that citations correlate well with a researcher's peer ratings, stature, and awards (Powell, 2016; Puckett, 2003). Citation analysis studies of the "most influential" or "most cited" authors or papers can provide insight into disciplinary priorities and scientific 
advancement (Hodge et al., 2012). Citations do not necessarily signify influence on practice, but do provide a measure of knowledge production and utilisation in the "academic and scientific enterprise" of social work (Kreisberg \& Marsh, 2016, p. 602).

There are important critiques of citation metrics as a means of determining research quality, especially in social sciences (Marson, 2020; Staller, 2017). Their increased use can be seen as part of the audit culture and, in common with other types of performance metrics, they have a discursive function in communicating policy intent, thereby shaping the way research quality is conceptualised (Tilbury, 2016). Clearly, research quality cannot be encapsulated in a single number. Research shows there is a bias toward citing authors known to the author personally, and a tendency towards within-country citations in social work publications, especially in the US but also in the UK (Slater, Scourfield, \& Sloan, 2012). Some studies have found that open access journals have a citation advantage over subscription journals by increasing visibility, findability, and accessibility of articles, although it is not causative (e.g., authors of high-quality papers may choose open access journals) (Gauléa \& Maystreb, 2011). It is asserted that factors such as cronyism, citing authors without consulting the work, self-citation, and poor referencing that does not correctly distinguish authors can inflate citation counts (e.g., Bornmann \& Daniel, 2008; Powell, 2016).

Other factors are reported to impact on citations and associated metrics. A paper might be frequently cited because it is controversial, regardless of its merits (Hodge et al., 2012), although it is possible to count citations per year to avoid outliers that have high shortterm effect but no long-term influence (Powell, 2016). Total citation numbers disadvantage early career researchers and women with interrupted research careers due to caring responsibilities, compared with others who have had more time to produce articles and other outputs (Wilsdon et al., 2015). Indigenous Australian scholars may have extra demands on 
their time to share cultural and professional expertise, for example, to advise on Indigenised curricula or sit on university committees, which reduce time for research (Asmar \& Page, 2018). Generally, men have longer careers so produce more papers than women; women publish more domestically so miss out on citations that international collaborations accrue; and men are more likely to self-cite so gender disparity worsens (Thyer, Smith, Osteen, \& Carter, 2019; Wilsdon et al., 2015). Early career academics are often on casual or teachingfocused contracts, which limit their capacity to research (Wilsdon et al., 2015). Location matters, because there are fewer non-US and non-English language journals covered in the indexing platforms that calculate citations (Wilsdon et al., 2015).

It is argued that the blunt use of metrics does not reflect the richness and plurality of research. The 2014 UK Review of the Role of Metrics in Research Assessment noted that the use of metrics has developed rapidly over the past 20 years as a potential method of measuring research quality and impact, but it remains the subject of considerable debate (Wilsdon et al., 2015). The pros and cons of bibliometric analyses of quality relate to "differences between academic subjects/disciplines; coverage of sources within databases; the selection of the appropriate unit of analysis for the indicator in question; the question of credit allocation where outputs may include multiple authors, and accounting for selfcitations" (Wilsdon et al., 2015, p. 30).

The tools for citation analysis are readily available online. The Hirsch or h-index, invented in 2005, "led to a surge of interest in individual level metrics" (Wilsdon et al., 2015, p. 13). The h-index is an author's number of articles $(h)$ that have received at least $h$ citations (Hirsch, 2005). For instance, a h-index of 10 means that the researcher has published at least 10 papers that have each been cited at least 10 times. It is designed to combine productivity (number of papers produced) and academic impact (number of citations) into a single number. There are three commonly used databases that calculate h-indexes: Web of Science, 
owned by Clarivate Analytics (previously Thomson Reuters publishing); Scopus, owned by Elsevier, a scientific publishing and information analytics company; and Google Scholar, owned by Google, specialising in internet-related products. There is also a downloadable software product, "Publish or Perish", which draws mainly on the Google Scholar database to calculate a range of citation metrics. All three web-based platforms enable searches to be conducted on authors, but there are limitations to the accessibility of information. For example, in Google Scholar (https://scholar.google.com) authors must allow their profiles to be public to view their h-index and list of publications. Scopus (https://www.scopus.com/freelookup/form/author.uri) and Web of Science (https://www.researcherid.com/\#rid-for-researchers) both provide h-indexes if the researcher has a profile (i.e., has published in an indexed journal), but Scopus provides "preview access" to the author's ten latest papers only. Sign-in via an institutional subscription is required to access the full record. There can be inaccuracies in all three databases if authors do not verify their publications, and there are particular problems for authors with common surnames (records may be merged) and authors who have published under different names or used different initials for given names.

Each database returns different h-index results due to differences in the sources from which citation counts are drawn. They each have relative merits and drawbacks. Publisherowned databases can be skewed toward their own journals. Coverage of social science and humanities scholarly literature (including books and book chapters) is limited compared with natural sciences, and coverage of non-US and non-English journals is limited (Hicks, 1999; Nederhof, 2006). Scopus has broader coverage of the social sciences than Web of Science. It is regarded as reputable for the social sciences, however many of the 105 journals listed for social work (Field of Research code 1607) in the 2018 ERA list are not indexed by Scopus. Web of Science is dominated by US journals and only covers books from 2005 onwards. It is 
considered to have the best coverage for natural and life sciences and was used to assess quality for the citation disciplines in ERA 2018. Google Scholar has better coverage of scholarly publications beyond journals indexed in publisher-owned databases and also includes grey literature. "Google Scholar is generally found to outperform both Web of Science and Scopus in terms of its coverage of the literature" (Wilsdon et.al., 2015, p. 31). In an analysis of citations in social work, Lasda Bergman (2012) found that Web of Science cited the fewest references, followed by Scopus, while Google Scholar provided much higher citation counts. There was little variation in source type for Scopus and Web of Science, with the majority of citations from journal articles. Google Scholar citations were sourced more widely from journals, books, theses, and non-English sources, with less than ten percent of citations from reports, blogs, reviews, websites, and presentation slides. In summary, Web of Science coverage of social work is more limited than Scopus, which is more limited than Google Scholar; however, Google Scholar is over inclusive, going beyond original published research. Consequently, whereas Google Scholar may over-count citations, Scopus and Web of Science are likely to under-count.

The aim of this paper is to contribute to empirical knowledge about the state of Australian social work scholarship. While there are shortcomings in citation analysis as a proxy for productivity and research quality, when used appropriately it is useful for assessing academic impact. The present paper examines h-indexes for Australian social work researchers according to stage of career. It complements research from other fields about discipline h-indexes, providing guidance for social work researchers interested in examining their own scholarly influence, and for research leaders involved in setting expectations about research output.

\section{Method}


The focus was publications produced by the social work profession rather than research from other disciplines using what might be regarded as social work frameworks, or research coded as social work (Field of Research 1607) in the national research classification system (Australian Bureau of Statistics, 2008). Social work researchers were defined as having a bachelor or masters-level social work qualification. This was determined from by-lines in articles, information from university websites, or from online research communities (e.g., ResearchGate, ORCID). We obtained and analysed h-indexes for social work researchers in a series of steps. First, we generated a sample of three categories of researchers:

1. Early career and mid-career researchers with a $\mathrm{PhD}$ awarded 2011 or after who were listed as working in one of the 29 universities offering an accredited social work degree according to the AASW website (www.aasw.asn.au);

2. Senior researchers with a $\mathrm{PhD}$ awarded 2010 or earlier who were listed as working in one of the 29 universities offering an AASW accredited program; and

3. Researchers based in research centres, who were more likely to have had research only or research-focussed positions for at least part of their career, and who were 10 years post$\mathrm{PhD}$.

We selected active researchers, using a threshold of at least one publication in either 2018 or 2019. The reason for this was to avoid teaching-focused academics for whom research and publication may not be a job requirement. We selected employees only, and no adjuncts (which are unpaid appointments). We aimed to include two people in each category from each institution. When there were more than two people in each category to choose from, we selected people with Scopus profiles, and people with more publications, to preference active researchers. Where possible we avoided selecting heads of schools or discipline leaders, because they often have administrative-focused workloads. We avoided people who appeared to have multiple Scopus profiles. ORCID profiles were used, when available, to link to 
correct Scopus profiles (ORCID is a non-profit organisation that commenced in 2012, which enables researchers to generate a single-digit unique researcher identifier). The three coauthors met the criteria and were included in the sample.

In accordance with Lasda Bergman's (2012) recommendation, we used all three databases - Google Scholar, Scopus, and Web of Science — to obtain the h-index and number of source documents (i.e., publications) for each researcher. Because the h-index changes with new publications and new citations, all searches were conducted between 23 March and 7 April 2020. We calculated descriptive statistics (average, median, range) on the h-index and number of publications and the period over which these were produced for each researcher. We supplemented data on productivity (i.e., number of publications) using the ERA output data, which are searchable on the Australian Research Council website (arc.gov.au/researchexcellence-australia). Performance data reported in the ERA 2012, 2015, and 2018 were used to provide a time series (Australian Research Council 2012; 2015; 2018).

The study used publicly available secondary data, so ethics approval was not necessary. Data were de-identified (researcher names, institution names, and ORCIDs were removed following analysis) because the focus was on aggregates rather than individual researchers.

\section{Findings}

Based on website searches, we selected 51 early/mid-career researchers, 53 senior researchers, and eight research-focused academics, total number 112. Some institutions did not have two people who met the inclusion criteria for each category. There were 23 universities with two early/mid researchers, five universities with one early/mid researcher, and one university with no early/mid researcher who met the criteria. All had at least one senior researcher: 24 universities had two seniors and five universities had one senior. Only seven universities had staff who met the research-focused criteria, one of those had two 
research-focused staff. Metrics for each researcher are listed in Supplementary Table 1.The gender breakdown was as follows: in the early/mid category, $78 \%(n=40)$ were women; in the senior category, $81 \%(n=43)$ were women; and in the research focused category $50 \%(n=4)$ were women. Identification of gender was based on our personal knowledge of the researcher and the personal pronouns used on websites, but there may be inaccuracies for people who identify as non-gender-specific or gender diverse, whom we assigned incorrectly as male or female.

\section{Omission of Web of Science metrics}

Problems were identified with Web of Science, which algorithmically generates author records based on publications harvested from indexed journals. For some authors, the record was correct (i.e., only included publications authored or co-authored by that person) and for others it was incorrect (usually because the publications of another author with the same or similar name were included), so their metrics were generated using publications they did not author. For the 112 researchers in our sample, there was a Web of Science record for all but one. As Table 1 shows, almost $85 \%$ of the total sample had not claimed their record. Early and mid-career researchers were the least likely to have claimed their record. Even the claimed records were not always accurate, with one or two additional records retrieved in an author search for seven of the 17 people. There were many unclaimed records where it was apparent from the author's name, field of research, or institutional affiliation that multiple profiles related to the same person. However, the main problem was the number of unclaimed records that included articles that had obviously not been created by that particular social work researcher. For example, articles by someone with the same name or a different middle initial had published in medical, animal science, or geophysics journals, but these were listed for the social work author. It was not always possible to determine inaccuracies, but the high number of unclaimed author records and obvious inaccuracies in records meant there could 
be little confidence in using Web of Science citation metrics in this study. It was notable that for the $17 \mathrm{Web}$ of Science author records that were claimed, there was parity with the Scopus metrics for that author.

Table 1 about here

\section{Scopus and Google Scholar citation metrics}

$\boldsymbol{H}$-indexes. As Table 2 shows, the average h-index for all social work researchers in the sample was 6.39 (Scopus) and 12.5 (Google Scholar). The average h-index for early and mid-career researchers according to Scopus was 3.2; range 0-9. According to Google Scholar the average h-index was 6.1; range 1-11. The Scopus average h-index for senior researchers was 8.1; range 1-22. Google Scholar average h-index for senior researchers was 15.7; range 3-41. The Scopus average h-index for research-focused social workers was 15.8; range 8-23. Google Scholar average h-index for the research-focused group was 25; range 8-38. Google Scholar average h-index for women was 12.2, range 2-38; compared with men 13.6, range 428. The Scopus average h-index for women was 6.8, range 0-24; compared with men 7.8, range 1-22.

\section{Table 2 about here}

Number of citations. According to Google Scholar there were 139 publications, written by 43 authors, which had each received 100 or more citations. Of the highly cited publications, three early/mid-career researchers each authored one publication; 104 of the publications were from 33 senior researchers; and 29 publications were from seven of the research-focused academics. Many of the highly cited publications in Google Scholar were books. There were far fewer highly cited publications according to Scopus - only 17 publications, written by 12 authors, had each received more than 100 citations, of which two were books. Of the highly cited publications in Scopus, one early/mid career researcher authored one document; 12 documents were from eight senior researchers; and four were 
from three of the research-focused academics. There was also a large number of never-cited publications. Because recently published papers are unlikely to have been cited, publications dated 2019 or 2020 were excluded when counting never-cited documents. In Scopus there were 294 pre-2019 publications, written by 79 authors, which had received zero citations. Of the never-cited publications, 28 early/mid-career researchers authored 59 publications; 195 were from 43 senior researchers; and 40 were from the eight research-focused academics. Google Scholar's coverage of a diverse array of sources, many of which are unlikely to receive citations (e.g., unrefereed conference abstracts), made the Google Scholar counts of never-cited publications unreliable.

Number of source documents (publications). See Table 3 for information about the number of documents from which the citations were sourced, and the average number according to category of researcher. In total, the 112 researchers produced 2533 documents, an average of 22.6 per researcher (Scopus) or 6426 documents, average 70.6 per researcher (Google Scholar). The timespan over which each researcher had published varied with the start of their research career. The longest career period was 36 years. The average period was 5.7 years for the early/mid group; 16.7 years for the senior researchers; and 19.0 years for the research-focused group. Refer to Supplementary Table 1 for information about how many publications each researcher produced.

Tables 3 and 4 about here

Annualised research output for all social work researchers in Australia was calculated using ERA data. See Table 4. These data are based on returns from researchers classified by their university into the social work field of research code 1607 (may include researchers with qualifications other than social work, e.g., human services qualifications). They represent outputs over six years (ending two years prior to the ERA assessment) and are not differentiated by stage of career. For all three ERA assessments, there was an upward trend in 
the number of outputs generated across the time period. Social work total research outputs submitted rose from 1706.9 in 2012 to 2253.9 in 2018 , a $24 \%$ increase, with only a $2 \%$ increase in FTE staff. When total research output was averaged across FTE staff, for ERA 2018, social work produced an average 8.5 outputs per FTE (1.4 outputs per FTE per year). Previous research based on ERA 2015 data found that social work outputs per FTE were slightly lower than those for comparable social science disciples of criminology and policy and administration (Tilbury, Hughes, Bigby, Fisher, \& Vogel, 2017).

\section{Discussion}

As expected, h-indexes and number of publications increased with seniority, because the longer a paper has been published the more chance there is of it being cited, and the longer you have been a researcher the more papers you are likely to have published. Using Scopus, the average h-index for early/mid-career social work academics up to 10 years post- $\mathrm{PhD}$ was 3.2; the average h-index for senior researchers was 8.1 , and the average h-index for researchfocused academics was 15.8. Consistent with previous research, average h-indexes for men were higher than those for women, reflecting comparative gender advantages. The h-indexes in Google Scholar (respectively $6.1 ; 15.7 ; 25.0$ ) were roughly twice the h-indexes in Scopus, as was the number of source documents. There is no evidence that either database is superior, they each have limitations, and can both be legitimately used. The highest h-index in our sample was 23 (Scopus) or 41 (Google Scholar) and these researchers should be regarded as influential discipline leaders. The average h-indexes for the Australian social work researchers compare favourably with US social work scholars. A 2011 study using Publish or Perish software involving 552 US social work faculty reported the average for professors was 16.14; associate professors 8.59; and assistant professors 3.97 (Lacasse, Hodge, \& Bean, 2011). A later study also using Publish or Perish, with 950 faculty from 25 highly-ranked social work programs, found the average h-index for professors was 9.45; associate 
professors 5.99; and assistant professors 3.57 (Barner, Holosko, \& Thyer, 2014). The latter study reported the average for all tenured and tenure-track social work faculty was 6.34 , standard deviation 5.57; compared with the Australian average using Google Scholar of 12.5; standard deviation 8.6.

There are many possible explanations for h-indexes of zero or one at the lower end of the range. Recent publications are generally not cited because they need a period of circulation to be read and cited in a subsequent publication, so the more time that has elapsed since an article was published, the more chance it has of being cited. Researchers have had fewer opportunities to publish if they only recently completed their $\mathrm{PhD}$, or recently obtained an academic appointment, or if they have experienced career interruptions. In the early part of their careers, many academics necessarily concentrate on teaching and can devote less time to research. However, academics who are several years post-PhD with low h-indexes may want to consider how to improve citations, such as publishing in journals with higher impact factors or ensuring their paper is available via open access. Multi-author papers tend to be cited more, a correlation also found for social work, where there has been a trend from sole author to multiple author publications over the past 20 years (Victor, Hodge, Perron, Vaughn, \& Salas-Wright, 2017).

There is no established benchmark for the number of citations to be expected, and benchmarks for "citation classics" differ by discipline. Powell (2016) defined citation classics in the social policy field as having more than $50 \mathrm{Web}$ of Science citations. Hodge et al. (2012) found that the 100 most-cited papers in social work discipline journals had between 242 and 41 citations and applied a benchmark of 100 Google Scholar citations to determine citation classics. While acknowledging the problems of citation counts, both studies concluded that they legitimately reflected intellectual significance within a discipline (Hodge et al., 2012; Powell, 2016). Therefore, while reiterating the caveats that citations alone do not 
signify quality, if a paper has been cited 50 times, it could be regarded as very good, and if it reaches the milestone of 100 citations then it could be regarded as a publication that has influenced the field. It is important to state that chasing citations should not be a goal - the objective is to do quality research, make an original contribution to knowledge, and disseminate findings - but publishing in respected journals with high circulation rates exposes research to a bigger readership and maximises its potential academic impact.

As noted, many universities already assess the productivity and quality of academics' research according to citation metrics. Benchmarks that are not discipline specific are highly problematic, due to differing research and publication traditions and patterns in disciplines. For example, compared with the natural sciences, social sciences and humanities research has (a) a more national and regional orientation, reflecting the importance of context in shaping society; (b) different publication traditions regarding books versus journal articles; (c) a different pace of theory development; and (d) different practices with regard to single scholar versus team research and publication (Nederhof, 2006). These characteristics all effect citations. Citation averages also differ per discipline due to the number of journals indexed in a field, longevity of the discipline in the academy, and gender composition of the discipline (Wilsdon et al., 2015). These factors can all reduce citations, but do not reflect lesser quality. There are metrics available that aim to normalise publication citations relative to a discipline ("field weighted citation impact" in the Scopus product SciVal and "category normalised citation impact" in the Clarivate product InCites) but these replicate the same problems with database coverage for social work.

It would be expected that the high proportion of women academics in social work would mean lower average h-indexes compared with gender-balanced or male-dominated disciplines. Likewise, the limitations on journal coverage in the indexing databases means that Australian researchers who publish a proportion of their papers in Australian journals are 
unlikely to receive the same citation numbers as their USA and UK counterparts. The Leiden Manifesto proposes ten guiding principles to guard against the uncritical use of publication metrics in research assessment (Hicks, Wouters, et.al., 2015). Importantly, it argues that variation by disciplinary field in publication and citation practices should be recognised; journal impact factors do not indicate the quality of articles within them; excellence in locally-relevant research should be protected; and any assessment of individual researchers should be based on qualitative expert judgement of their whole portfolio. Based on the present study, a citation benchmark for social work would be in the range of h-index 3.2 for early career researchers to 15.8 for research-focused positions (using Scopus) or h-index 6.1 to 25.0 (using Google Scholar). A social work benchmark for number of publications would be around 1.4 publications per year, depending upon stage of career and workload profile. Caution is needed with publication benchmarks because they can have the perverse effect of privileging quantity over quality, resulting in people reaching the required number of publications, but with few citations.

Depth of knowledge in a research field requires attention to both quantity and quality of publications. Researchers should aim to write publications that are useful to other scholars and that influence the field. Publishing in the top journals in the field (or sub-field) maximises readership, so from the early stages of their career, researchers should target journals that publish highly-cited work (i.e., with higher impact factors), where the leading scholars in their field publish. Increasing access to postdoctoral fellowships for social work to enable a focus on research immediately after finishing a $\mathrm{PhD}$ would be advantageous. It is clearly in the interests of researchers to check, correct, and claim their Google Scholar, Scopus, and Web of Science records, and to link all three to their ORCID profile. That said, correcting Scopus and Web of Science profiles is not straightforward and there is a time lag. Minor amendments can be made by authors, but requests to merge author profiles, add 
missing documents, or correct citations involve submitting a web-based request. The advantage of ORCID is that researchers can amend their own profiles to add missing publications and delete incorrectly assigned publications. ORCID uptake has rapidly grown internationally and "is widely regarded as the best" (Wilsdon et al., 2018, p. 18). Researchers making Australian Research Council grant applications are now required to provide an ORCID web link to replace manually compiled publication lists.

Limitations. The findings of this study should be understood within the limitations of citation analysis outlined above. We reiterate that cited papers are not necessarily high quality and the h-index, while widely used, is a proxy for quality. We had no means to ascertain workload profiles to account for administration, teaching, and service loads, fractional appointments, or career breaks. These may change over time providing relatively more or less time available for research. We used h-indexes reported on databases without checking each person's citations, given this was a study of aggregates, not individuals. The study presents a point-in-time analysis and the number of documents and citations may have changed at time of publication. Nevertheless, the general findings are likely to remain stable over time.

Conclusion. This study contributes to a growing body of research about disciplinary norms in the production and dissemination of social work scholarship. To our knowledge, it is the first published study of h-indexes for Australian social work researchers. The accuracy and reliability of citation metrics will be much improved if social work researchers claim, update, and link their Google Scholar, Scopus, Web of Science, and ORCID profiles.

Acknowledgements: This research was supported by Australian Research Council grant DP170102412 Advancing the production, utilisation, and impact of social work research to generate innovation in human services. 


\section{References}

Asmar, C. and Page, S. (2018) Pigeonholed, peripheral or pioneering? Findings from a national study of Indigenous Australian academics in the disciplines, Studies in Higher Education, 43(9), 1679-1691. doi 10.1080/03075079.2017.1281240

Australian Bureau of Statistics (2008b). Australian and New Zealand Standard Research Classification 2008, Cat. No. 1297.0. Canberra: Author.

Australian Research Council (ARC) (2012). Excellence in Research for Australia 2012 National Report. Retrieved from https://www.arc.gov.au/excellence-research-australia Australian Research Council (ARC) (2015). State of Australian University Research 201516: Volume 1 ERA National Report. Retrieved from https://www.arc.gov.au/excellence-research-australia

Australian Research Council (ARC) (2018) State of Australian University Research 2018-19: ERA National Report. Retrieved from https://www.arc.gov.au/excellence-research$\underline{\text { australia }}$

Barner, J. R., Holosko, M. J., \& Thyer, B. A. (2013). American social work and psychology faculty members' scholarly productivity: A controlled comparison of citation impact using the H-Index. British Journal of Social Work, 44(8), 2448-2458.

Bornmann, L. \& Hans-Dieter, D. (2008). What do citation counts measure? A review of studies on citing behaviour. Journal of Documentation, 64(1), 45-80. doi/10.1108/00220410810844150

Gauléa, P. \& Maystreb, N. (2011). Getting cited: Does open access help? Research Policy, 40(10), 1332-1338. doi.org/10.1016/j.respol.2011.05.025

Hicks, D. (1999). The difficulty of achieving full coverage of international social science literature and the bibliometric consequences. Scientometrics, 44(2), 193-215. 
Hicks, D., Wouters, P., Waltman, L., de Rijcke, S. \& Rafols, I. (2015). The Leiden Manifesto for research metrics. Nature, 520, 429-431.

Hirsch, J. E. (2005). An index to quantify an individual's scientific research output.

Proceedings of the National Academy of Sciences, 102(46), 16569-16572.

doi.org/10.1073/pnas.0507655102

Hodge, D., Lacasse, J., \& Benson, O. (2012). Influential publications in social work discourse: The 100 most highly cited articles in disciplinary journals 2008-09. British Journal of Social Work, 42(4), 765-782.

Kreisberg, N., \& Marsh, J.C. (2016). Social work knowledge production and utilisation: An international comparison. British Journal of Social Work, 46(3), 599618. doi.org/10.1093/bjsw/bcu147

Lacasse, J.R., Hodge, D.R., \& Bean, K.F. (2011). Evaluating the productivity of social work scholars using the h-index. Research on Social Work Practice, 21(5), 599-607.

Lasda Bergman, E. M. (2012). Finding citations to social work literature: The relative benefits of using Web of Science, Scopus, or Google Scholar. Journal of Academic Librarianship, 38(6), 370-379.

Marson, S.M. (2020) Editorial: Is the impact factor (IF) ethical to use for promotion and tenure decisions? Journal of Social Work Values and Ethics, 17(1), 2-5.

Nederhof, A. J. (2006). Bibliometric monitoring of research performance in the social sciences and the humanities: A review. Scientometrics, 66(1), 81-100.

Powell, M. (2016). Citation classics in social policy journals. Social Policy \& Administration, $50(6), 648-672$.

Puckett, T. (2003). Australia's leading social work authors. Australian Social Work, 56(3), 267-274. 
Slater, T., Scourfield, J., \& Sloan, L. (2012). Who is citing whom in social work? A response to Hodge, Lacasse and Benson. British Journal of Social Work, 42(8), 1626-1633.

Staller, K. M. (2017). Accountability metrics, politics, and qualitative inquiry: Demystifying bibliometrics. Qualitative Social Work, 16(4), 437-445. doi.org/10.1177/1473325017713881

Thyer, B. A., Smith, T. E., Osteen, P., \& Carter, T. (2019). The 100 most influential contemporary social work faculty as assessed by the H-Index. Journal of Social Service Research, 45(5), 696-00. doi: 10.1080/01488376.2018.1501793

Tilbury, C. (2016). Repositioning prevention using performance indicators. Policy Studies, 37(6), 583-596. doi 10.1080/01442872.2015.1110236

Tilbury, C., Hughes, M., Bigby, C., Fisher, M., \& Vogel, L. (2017) A comparative study of Australian social work research, British Journal of Social Work, 47(8), 2217-2237. doi 10.1093/bjsw/bcw135

Victor, B.G., Hodge, D.R., Perron, B.E., Vaughn, M.G., Salas-Wright, C.P. (2017). The rise of co-authorship in social work scholarship: A longitudinal study of collaboration and article quality 1989-2013, British Journal of Social Work, 47(8), 2201-2216. doi.org/10.1093/bjsw/bcw059

Wilsdon, J., Allen, L., Belfiore, E., Campbell, P., Curry, S., Hill, S., Jones, R., Kain, R., Kerridge, S., Thelwall, M., Tinkler, J., Viney, I., Wouters, P., Hill, J., \& Johnson, B. (2015). The Metric Tide: Report of the Independent Review of the Role of Metrics in Research Assessment and Management. doi: 10.13140/RG.2.1.4929.1363 
Table 1

Researchers with a claimed Web of Science profile

Category Author has claimed profile

Early and mid career researcher $(\mathrm{n}=51)$ $3(5.8 \%)$

Senior researcher $(n=53)$

$13(24.5 \%)$

Research focused ( $\mathrm{n}=8)$

$1(12.5 \%)$

Total $(\mathrm{n}=112)$

$17(15.2 \%)$ 


\section{Table 2}

\section{H-indexes for social work researchers in Scopus and Google Scholar}

Early and mid-career

Scopus $(n=51)($ sum of h-indexes $=161) \quad$ Google Scholar $\left(n=38^{a}\right)($ sum of h-indexes $=232)$

Average: 3.2

Average: 6.1

Range: 0 to 9

Range: 1 to 11

Senior

Scopus $(\mathrm{n}=53)($ sum of h-indexes $=429) \quad$ Google Scholar $\left(\mathrm{n}=45^{\mathrm{b}}\right)($ sum of h-indexes $=706)$

Average: 8.1

Average: 15.7

Range: 1 to 22

Range: 3 to 41

Research-focused

Scopus $(n=8)($ sum of h-indexes $=126) \quad$ Google Scholar $(n=8)($ sum of h-indexes $=200)$

Average: 15.8

Average: 25.0

Range: 8 to 23

Range: 18 to 38

Average for all researchers

Scopus 6.4

Google Scholar 12.5

${ }^{a} 13$ without Google Scholar public profile

b8 without Google Scholar Public profile 
Table 3

Documents for social work researchers in Scopus and Google Scholar

Early and mid-career

Scopus $(n=51) \quad$ Google Scholar $\left(n=38^{a}\right)$

Total documents $450 \quad$ Total documents 1038

Average: 8.8

Average: 27.3

Range: 1 to 24

Range: 5 to 71

Senior

Scopus $(n=53)$

Google Scholar $\left(n=45^{b}\right)$

Total documents 1467

Total documents 3954

Average: 27.7

Average: 87.9

Range: 2 to 90

Range: 14 to 446

Research focused

Scopus $(\mathrm{n}=8)$

Google Scholar $(\mathrm{n}=8)$

Total documents 616

Total documents 1437

Average: 77

Average: 179.6

Range: 42 to 150

Range: 67 to 483

All researchers

Total number of documents $=2533$

Total number of documents $=6429$

Average: 22.6

Average: 57.4

${ }^{a} 13$ without Google Scholar public profile

b8 without Google Scholar public profile 


\section{Table 4}

Research outputs submitted for ERA 2012, 2015 and 2018 for social work, Field of Research code 1607

\begin{tabular}{lccc}
\hline Year & 2012 & 2015 & 2018 \\
Period covered & $2005-2010$ & $2008-2013$ & $2011-2016$ \\
\hline Total apportioned research outputs & 1706.9 & 2097.4 & 2253.9 \\
submitted & & & \\
Average outputs per FTE over the & 6.56 & 7.99 & 8.46 \\
assessment period & & & \\
Average outputs per FTE per year & 1.1 & 1.3 & 1.4 \\
\hline
\end{tabular}


Supplementary Table 1: Citation metrics for Australian social work researchers 2020

\begin{tabular}{|c|c|c|c|}
\hline \multicolumn{4}{|c|}{ Early and mid career social work researchers $(n=51)$} \\
\hline & $\begin{array}{l}\text { Year doctorate } \\
\text { awarded }\end{array}$ & $\begin{array}{l}\text { Scopus } \\
\text { Number of } \\
\text { documents/ } \\
\text { h-index }\end{array}$ & $\begin{array}{l}\text { Google scholar: } \\
\text { Number of documents/ } \\
\text { h-index }\end{array}$ \\
\hline 1 & 2012 & $\begin{array}{l}20 \text { docs } \\
\text { h-index } 9\end{array}$ & No public profile \\
\hline 2 & 2017 & $\begin{array}{l}24 \text { docs } \\
\text { h-index } 7\end{array}$ & $\begin{array}{l}57 \text { docs } \\
\mathrm{h} \text {-index } 10\end{array}$ \\
\hline 3 & 2017 & $\begin{array}{l}12 \text { docs } \\
\text { h-index } 7\end{array}$ & $\begin{array}{l}29 \text { docs } \\
\text { h-index } 10\end{array}$ \\
\hline 4 & 2012 & $\begin{array}{l}22 \text { docs } \\
\text { h-index } 6\end{array}$ & $\begin{array}{l}71 \text { docs } \\
\mathrm{h} \text {-index } 11 \\
\end{array}$ \\
\hline 5 & 2011 & $\begin{array}{l}19 \text { docs } \\
\text { h-index } 6\end{array}$ & $\begin{array}{l}27 \text { docs } \\
\text { h-index } 8\end{array}$ \\
\hline 6 & 2011 & $\begin{array}{l}15 \text { docs } \\
\text { h-index } 6\end{array}$ & $\begin{array}{l}35 \text { docs } \\
\text { h-index } 9\end{array}$ \\
\hline 7 & 2014 & $\begin{array}{l}15 \text { docs } \\
\text { h-index } 6\end{array}$ & $\begin{array}{l}25 \text { docs } \\
\text { h-index } 9\end{array}$ \\
\hline 8 & 2012 & $\begin{array}{l}19 \text { docs } \\
\text { h-index } 5\end{array}$ & $\begin{array}{l}49 \text { docs } \\
\text { h-index } 9\end{array}$ \\
\hline 9 & 2012 & $\begin{array}{l}18 \text { docs } \\
\text { h-index } 5\end{array}$ & No public profile \\
\hline 10 & 2011 & $\begin{array}{l}11 \text { docs } \\
\text { h-index } 5\end{array}$ & $\begin{array}{l}23 \text { docs } \\
\text { h-index } 6\end{array}$ \\
\hline 11 & 2011 & $\begin{array}{l}19 \text { docs } \\
\text { h-index } 4\end{array}$ & $\begin{array}{l}37 \text { docs } \\
\text { h-index } 6\end{array}$ \\
\hline 12 & 2015 & $\begin{array}{l}16 \text { docs } \\
\text { h-index } 4\end{array}$ & $\begin{array}{l}71 \text { docs } \\
\text { h-index } 9\end{array}$ \\
\hline 13 & 2013 & $\begin{array}{l}16 \text { docs } \\
\text { h-index } 4\end{array}$ & $\begin{array}{l}47 \text { docs } \\
\text { h-index } 8\end{array}$ \\
\hline 14 & 2014 & $\begin{array}{l}14 \text { docs } \\
\text { h-index } 4\end{array}$ & $\begin{array}{l}55 \text { docs } \\
\text { h-index } 6\end{array}$ \\
\hline 15 & 2013 & $\begin{array}{l}13 \text { docs } \\
\text { h-index } 4\end{array}$ & No public profile \\
\hline 16 & 2017 & $\begin{array}{l}12 \text { docs } \\
\text { h-index } 4\end{array}$ & $\begin{array}{l}27 \text { docs } \\
\text { h-index } 9\end{array}$ \\
\hline 17 & 2013 & $\begin{array}{l}11 \text { docs } \\
\text { h-index } 4\end{array}$ & $\begin{array}{l}23 \text { docs } \\
\text { h-index } 7\end{array}$ \\
\hline 18 & 2015 & $\begin{array}{l}11 \text { docs } \\
\text { h-index } 4 \\
\end{array}$ & $\begin{array}{l}29 \text { docs } \\
\text { h-index } 9\end{array}$ \\
\hline 19 & 2015 & $\begin{array}{l}9 \text { docs } \\
\text { h-index } 4\end{array}$ & $\begin{array}{l}32 \text { docs } \\
\text { h-index } 6\end{array}$ \\
\hline 20 & 2015 & $\begin{array}{l}8 \text { docs } \\
\text { h-index } 4\end{array}$ & $\begin{array}{l}12 \text { docs } \\
\text { h-index } 8\end{array}$ \\
\hline 21 & 2013 & $\begin{array}{l}12 \text { docs } \\
\mathrm{h} \text {-index } 3\end{array}$ & $\begin{array}{l}38 \text { docs } \\
\text { h-index } 5\end{array}$ \\
\hline 22 & 2012 & $\begin{array}{l}11 \text { docs } \\
\text { h-index } 3\end{array}$ & $\begin{array}{l}19 \text { docs } \\
\text { h-index } 7\end{array}$ \\
\hline 23 & 2017 & 8 docs & 21 docs \\
\hline
\end{tabular}




\begin{tabular}{|c|c|c|c|}
\hline & & h-index 3 & h-index 5 \\
\hline 24 & 2012 & $\begin{array}{l}8 \text { docs } \\
\text { h-index } 3\end{array}$ & No public profile \\
\hline 25 & 2014 & $\begin{array}{l}7 \text { docs } \\
\mathrm{h} \text {-index } 3 \\
\end{array}$ & No public profile \\
\hline 26 & 2018 & $\begin{array}{l}6 \text { docs } \\
\text { h-index } 3\end{array}$ & No public profile \\
\hline 27 & 2014 & $\begin{array}{l}6 \text { docs } \\
\text { h-index } 3\end{array}$ & $\begin{array}{l}10 \text { docs } \\
\text { h-index } 3\end{array}$ \\
\hline 28 & 2015 & $\begin{array}{l}5 \text { docs } \\
\mathrm{h} \text {-index } 3 \\
\end{array}$ & $\begin{array}{l}10 \text { docs } \\
\text { h-index } 4\end{array}$ \\
\hline 29 & 2016 & $\begin{array}{l}4 \text { docs } \\
\text { h-index } 3\end{array}$ & $\begin{array}{l}7 \text { docs } \\
\text { h-index } 3 \\
\end{array}$ \\
\hline 30 & 2014 & $\begin{array}{l}4 \text { docs } \\
\text { h-index } 3\end{array}$ & No public profile \\
\hline 31 & 2014 & $\begin{array}{l}4 \text { docs } \\
\text { h-index } 3\end{array}$ & $\begin{array}{l}28 \text { docs } \\
\text { h-index } 7\end{array}$ \\
\hline 32 & 2013 & $\begin{array}{l}4 \text { docs } \\
\text { h-index } 3\end{array}$ & $\begin{array}{l}8 \text { docs } \\
\text { h-index } 4\end{array}$ \\
\hline 33 & 2017 & $\begin{array}{l}10 \text { docs } \\
\text { h-index } 2\end{array}$ & $\begin{array}{l}27 \text { docs } \\
\text { h-index } 4\end{array}$ \\
\hline 34 & 2014 & $\begin{array}{l}6 \text { docs } \\
\text { h-index } 2 \\
\end{array}$ & $\begin{array}{l}14 \text { docs } \\
\text { h-index } 5\end{array}$ \\
\hline 35 & 2017 & $\begin{array}{l}5 \text { docs } \\
\text { h-index } 2\end{array}$ & $\begin{array}{l}24 \text { docs } \\
\text { h-index } 5\end{array}$ \\
\hline 36 & 2015 & $\begin{array}{l}5 \text { docs } \\
\mathrm{h} \text {-index } 2 \\
\end{array}$ & $\begin{array}{l}15 \text { docs } \\
\text { h-index } 4\end{array}$ \\
\hline 37 & 2017 & $\begin{array}{l}3 \text { docs } \\
\text { h-index } 2\end{array}$ & $\begin{array}{l}5 \text { docs } \\
\mathrm{h} \text {-index } 2\end{array}$ \\
\hline 38 & 2017 & $\begin{array}{l}3 \text { docs } \\
\text { h-index } 2\end{array}$ & $\begin{array}{l}28 \text { docs } \\
\text { h-index } 8\end{array}$ \\
\hline 39 & 2014 & $\begin{array}{l}3 \text { docs } \\
\text { h-index } 2\end{array}$ & No public profile \\
\hline 40 & 2017 & $\begin{array}{l}7 \text { docs } \\
\text { h-index } 1\end{array}$ & $\begin{array}{l}43 \text { docs } \\
\text { h-index } 5\end{array}$ \\
\hline 41 & 2017 & $\begin{array}{l}4 \text { docs } \\
\text { h-index } 1\end{array}$ & $\begin{array}{l}29 \text { docs } \\
\text { h-index } 6\end{array}$ \\
\hline 42 & 2013 & $\begin{array}{l}4 \text { docs } \\
\mathrm{h} \text {-index } 1\end{array}$ & $\begin{array}{l}30 \text { docs } \\
\text { h-index } 6\end{array}$ \\
\hline 43 & 2012 & $\begin{array}{l}3 \text { docs } \\
\text { h-index } 1 \\
\end{array}$ & No public profile \\
\hline 44 & 2015 & $\begin{array}{l}3 \text { docs } \\
\mathrm{h} \text {-index } 1\end{array}$ & No public profile \\
\hline 45 & 2016 & $\begin{array}{l}2 \text { docs } \\
\text { h-index } 1\end{array}$ & No public profile \\
\hline 46 & 2014 & $\begin{array}{l}2 \text { docs } \\
\mathrm{h} \text {-index } 1\end{array}$ & $\begin{array}{l}12 \text { docs } \\
\text { h-index } 4\end{array}$ \\
\hline 47 & 2018 & $\begin{array}{l}1 \text { doc } \\
\text { h-index } 1\end{array}$ & No public profile \\
\hline 48 & 2013 & $\begin{array}{l}1 \text { doc } \\
\text { h-index } 1\end{array}$ & No public profile \\
\hline 49 & 2014 & $\begin{array}{l}3 \text { docs } \\
\mathrm{h} \text {-index } 0\end{array}$ & $\begin{array}{l}6 \text { docs } \\
\text { h-index } 1 \\
\end{array}$ \\
\hline 50 & 2013 & $1 \mathrm{doc}$ & 10 docs \\
\hline
\end{tabular}




\begin{tabular}{|c|c|c|c|}
\hline & & h-index 0 & h-index 2 \\
\hline 51 & 2016 & $\begin{array}{l}1 \text { doc } \\
\text { h-index } 0\end{array}$ & $\begin{array}{l}5 \text { docs } \\
\text { h-index } 2\end{array}$ \\
\hline \multicolumn{4}{|c|}{ Senior social work researchers $(\mathrm{n}=53)$} \\
\hline & $\begin{array}{l}\text { Year Doctorate } \\
\text { awarded }\end{array}$ & $\begin{array}{l}\text { Scopus metrics: } \\
\text { Number of } \\
\text { documents/ h-index }\end{array}$ & $\begin{array}{l}\text { Google Scholar } \\
\text { metrics: Number of } \\
\text { documents/ h-index }\end{array}$ \\
\hline 52 & 1993 & $\begin{array}{l}89 \text { docs } \\
\text { h-index } 22\end{array}$ & $\begin{array}{l}215 \text { docs } \\
\text { h-index } 41\end{array}$ \\
\hline 53 & 1995 & $\begin{array}{l}90 \text { docs } \\
\text { h-index } 20\end{array}$ & $\begin{array}{l}281 \text { docs } \\
\text { h-index } 32\end{array}$ \\
\hline 54 & 1997 & $\begin{array}{l}47 \text { docs } \\
\text { h-index } 19\end{array}$ & $\begin{array}{l}150 \text { docs } \\
\text { h-index } 32\end{array}$ \\
\hline 55 & 1997 & $\begin{array}{l}64 \text { docs } \\
\text { h-index } 16\end{array}$ & No public profile \\
\hline 56 & 1992 & $\begin{array}{l}58 \text { docs } \\
\text { h-index } 16\end{array}$ & $\begin{array}{l}126 \text { docs } \\
\text { h-index } 22\end{array}$ \\
\hline 57 & 1996 & $\begin{array}{l}85 \text { docs } \\
\text { h-index } 14\end{array}$ & $\begin{array}{l}446 \text { docs } \\
\text { h-index } 28\end{array}$ \\
\hline 58 & 2010 & $\begin{array}{l}48 \text { docs } \\
\text { h-index } 14\end{array}$ & $\begin{array}{l}89 \text { docs } \\
\text { h-index } 21\end{array}$ \\
\hline 59 & Pre 2009 & $\begin{array}{l}62 \text { docs } \\
\mathrm{h} \text {-index } 13\end{array}$ & $\begin{array}{l}136 \text { docs } \\
\mathrm{h} \text {-index } 20\end{array}$ \\
\hline 60 & 2003 & $\begin{array}{l}41 \text { docs } \\
\text { h-index } 13\end{array}$ & $\begin{array}{l}68 \text { docs } \\
\text { h-index } 20\end{array}$ \\
\hline 61 & 2005 & $\begin{array}{l}38 \text { docs } \\
\text { h-index } 12\end{array}$ & $\begin{array}{l}80 \text { docs } \\
\text { h-index } 20\end{array}$ \\
\hline 62 & 2009 & $\begin{array}{l}61 \text { docs } \\
\mathrm{h} \text {-index } 11\end{array}$ & $\begin{array}{l}121 \text { docs } \\
\text { h-index } 15\end{array}$ \\
\hline 63 & 2004 & $\begin{array}{l}47 \text { docs } \\
\text { h-index } 11\end{array}$ & $\begin{array}{l}91 \text { docs } \\
\text { h-index } 20\end{array}$ \\
\hline 64 & 1996 & $\begin{array}{l}42 \text { docs } \\
\text { h-index } 11\end{array}$ & $\begin{array}{l}68 \text { docs } \\
\text { h-index } 19\end{array}$ \\
\hline 65 & 2002 & $\begin{array}{l}36 \text { docs } \\
\text { h-index } 11\end{array}$ & $\begin{array}{l}89 \text { docs } \\
\text { h-index } 19\end{array}$ \\
\hline 66 & 2000 & $\begin{array}{l}25 \text { docs } \\
\text { h-index } 11\end{array}$ & $\begin{array}{l}44 \text { docs } \\
\text { h-index } 16\end{array}$ \\
\hline 67 & 2003 & $\begin{array}{l}17 \text { docs } \\
\text { h-index } 11\end{array}$ & $\begin{array}{l}102 \text { docs } \\
\text { h-index } 20\end{array}$ \\
\hline 68 & 2001 & $\begin{array}{l}33 \text { docs } \\
\text { h-index } 10\end{array}$ & $\begin{array}{l}186 \text { docs } \\
\text { h-index } 24\end{array}$ \\
\hline 69 & 2010 & $\begin{array}{l}28 \text { docs } \\
\mathrm{h} \text {-index } 10\end{array}$ & $\begin{array}{l}40 \text { docs } \\
\text { h-index } 12\end{array}$ \\
\hline 70 & 2004 & $\begin{array}{l}26 \text { docs } \\
\text { h-index } 10\end{array}$ & $\begin{array}{l}81 \text { docs } \\
\text { h-index } 21\end{array}$ \\
\hline 71 & 1996 & $\begin{array}{l}24 \text { docs } \\
\mathrm{h} \text {-index } 10\end{array}$ & $\begin{array}{l}96 \text { docs } \\
\text { h-index } 21\end{array}$ \\
\hline 72 & 1996 & $\begin{array}{l}38 \text { docs } \\
\text { h-index } 9\end{array}$ & $\begin{array}{l}92 \text { docs } \\
\text { h-index } 13\end{array}$ \\
\hline 73 & pre 1999 & $\begin{array}{l}60 \text { docs } \\
\text { h-index } 8\end{array}$ & $\begin{array}{l}160 \text { docs } \\
\text { h-index } 18\end{array}$ \\
\hline 74 & 2003 & $\begin{array}{l}21 \text { docs } \\
\text { h-index } 8\end{array}$ & $\begin{array}{l}103 \text { docs } \\
\text { h-index } 20\end{array}$ \\
\hline
\end{tabular}




\begin{tabular}{|c|c|c|c|}
\hline 75 & 2007 & $\begin{array}{l}18 \text { docs } \\
\text { h-index } 8\end{array}$ & No public profile \\
\hline 76 & 2001 & $\begin{array}{l}15 \text { docs } \\
\text { h-index } 8\end{array}$ & $\begin{array}{l}66 \text { docs } \\
\text { h-index } 11\end{array}$ \\
\hline 77 & 2004 & $\begin{array}{l}14 \text { docs } \\
\text { h-index } 8\end{array}$ & $\begin{array}{l}29 \text { docs } \\
\text { h-index } 12\end{array}$ \\
\hline 78 & 2009 & $\begin{array}{l}31 \text { docs } \\
\text { h-index } 7\end{array}$ & No public profile \\
\hline 79 & 2005 & $\begin{array}{l}23 \text { docs } \\
\text { h-index } 7\end{array}$ & $\begin{array}{l}50 \text { docs } \\
\text { h-index } 13\end{array}$ \\
\hline 80 & 2009 & $\begin{array}{l}18 \text { docs } \\
\text { h-index } 7\end{array}$ & $\begin{array}{l}52 \text { docs } \\
\text { h-index } 12\end{array}$ \\
\hline 81 & 1995 & $\begin{array}{l}18 \text { docs } \\
\text { h-index } 7\end{array}$ & $\begin{array}{l}88 \text { docs } \\
\text { h-index } 17\end{array}$ \\
\hline 82 & 2010 & $\begin{array}{l}16 \text { docs } \\
\text { h-index } 7\end{array}$ & $\begin{array}{l}93 \text { docs } \\
\text { h-index } 17\end{array}$ \\
\hline 83 & 2007 & $\begin{array}{l}32 \text { docs } \\
\text { h-index } 6\end{array}$ & $\begin{array}{l}71 \text { docs } \\
\text { h-index } 12\end{array}$ \\
\hline 84 & 2002 & $\begin{array}{l}27 \text { docs } \\
\text { h-index } 6\end{array}$ & $\begin{array}{l}83 \text { docs } \\
\text { h-index } 14 \\
\end{array}$ \\
\hline 85 & 2005 & $\begin{array}{l}11 \text { docs } \\
\text { h-index } 6\end{array}$ & $\begin{array}{l}43 \text { docs } \\
\text { h-index } 11\end{array}$ \\
\hline 86 & 1983 & $\begin{array}{l}11 \text { docs } \\
\text { h-index } 6\end{array}$ & $\begin{array}{l}91 \text { docs } \\
\text { h-index } 22\end{array}$ \\
\hline 87 & 2003 & $\begin{array}{l}15 \text { docs } \\
\text { h-index } 5\end{array}$ & No public profile \\
\hline 88 & 2009 & $\begin{array}{l}11 \text { docs } \\
\text { h-index } 5\end{array}$ & $\begin{array}{l}33 \text { docs } \\
\text { h-index } 8\end{array}$ \\
\hline 89 & 2000 & $\begin{array}{l}9 \text { docs } \\
\text { h-index } 5\end{array}$ & $\begin{array}{l}24 \text { docs } \\
\text { h-index } 7\end{array}$ \\
\hline 90 & 2009 & $\begin{array}{l}8 \text { docs } \\
\text { h-index } 5\end{array}$ & $\begin{array}{l}32 \text { docs } \\
\text { h-index } 8\end{array}$ \\
\hline 91 & 1999 & $\begin{array}{l}14 \text { docs } \\
\text { h-index } 4\end{array}$ & No public profile \\
\hline 92 & 1998 & $\begin{array}{l}10 \text { docs } \\
\text { h-index } 4\end{array}$ & $\begin{array}{l}44 \text { docs } \\
\text { h-index } 10\end{array}$ \\
\hline 93 & 2007 & $\begin{array}{l}6 \text { docs } \\
\text { h-index } 4\end{array}$ & $\begin{array}{l}17 \text { docs } \\
\text { h-index } 8\end{array}$ \\
\hline 94 & 2009 & $\begin{array}{l}11 \text { docs } \\
\text { h-index } 3\end{array}$ & $\begin{array}{l}34 \text { docs } \\
\text { h-index } 7\end{array}$ \\
\hline 95 & 2005 & $\begin{array}{l}7 \text { docs } \\
\text { h-index } 3\end{array}$ & No public profile \\
\hline 96 & 2010 & $\begin{array}{l}6 \text { docs } \\
\text { h-index } 3\end{array}$ & $\begin{array}{l}29 \text { docs } \\
\text { h-index } 4\end{array}$ \\
\hline 97 & 2010 & $\begin{array}{l}5 \text { docs } \\
\text { h-index } 3\end{array}$ & $\begin{array}{l}17 \text { docs } \\
\text { h-index } 5\end{array}$ \\
\hline 98 & 2009 & $\begin{array}{l}12 \text { docs } \\
\text { h-index } 2\end{array}$ & $\begin{array}{l}73 \text { docs } \\
\text { h-index } 9\end{array}$ \\
\hline 99 & 2010 & $\begin{array}{l}9 \text { docs } \\
\text { h-index } 2\end{array}$ & $\begin{array}{l}14 \text { docs } \\
\text { h-index } 3\end{array}$ \\
\hline 100 & 2009 & $\begin{array}{l}6 \text { docs } \\
\text { h-index } 2\end{array}$ & $\begin{array}{l}36 \text { docs } \\
\text { h-index } 8\end{array}$ \\
\hline 101 & 2007 & $\begin{array}{l}6 \text { docs } \\
\text { h-index } 2\end{array}$ & No public profile \\
\hline
\end{tabular}




\begin{tabular}{|c|c|c|c|}
\hline 102 & 2010 & $\begin{array}{l}5 \text { docs } \\
\text { h-index } 2\end{array}$ & No public profile \\
\hline 103 & 2008 & $\begin{array}{l}11 \text { docs } \\
\text { h-index } 1\end{array}$ & $\begin{array}{l}55 \text { docs } \\
\text { h-index } 11\end{array}$ \\
\hline 104 & 2008 & $\begin{array}{l}2 \text { docs } \\
\mathrm{h} \text {-index } 1\end{array}$ & $\begin{array}{l}16 \text { docs } \\
\text { h-index } 3\end{array}$ \\
\hline \multicolumn{4}{|c|}{ Research-focussed social work researchers $(n=8)$} \\
\hline & $\begin{array}{l}\text { Year Doctorate } \\
\text { awarded }\end{array}$ & $\begin{array}{l}\text { Scopus metrics: } \\
\text { Number of } \\
\text { documents/ h-index }\end{array}$ & $\begin{array}{l}\text { Google Scholar } \\
\text { metrics: Number of } \\
\text { documents/ h-index }\end{array}$ \\
\hline 105 & 1996 & $\begin{array}{l}150 \text { docs } \\
\text { h-index } 23\end{array}$ & $\begin{array}{l}483 \text { docs } \\
\mathrm{h} \text {-index } 38\end{array}$ \\
\hline 106 & 2004 & $\begin{array}{l}92 \text { docs } \\
\text { h-index } 22\end{array}$ & $\begin{array}{l}82 \text { docs } \\
\text { h-index } 28\end{array}$ \\
\hline 107 & 1991 & $\begin{array}{l}100 \text { docs } \\
\text { h-index } 19\end{array}$ & $\begin{array}{l}208 \text { docs } \\
\text { h-index } 31\end{array}$ \\
\hline 108 & 2001 & $\begin{array}{l}63 \text { docs } \\
\text { h-index } 17\end{array}$ & $\begin{array}{l}144 \text { docs } \\
\text { h-index } 22\end{array}$ \\
\hline 109 & 2010 & $\begin{array}{l}4 \text { docs } \\
\text { h-index } 13\end{array}$ & $\begin{array}{l}111 \text { docs } \\
\text { h-index } 21\end{array}$ \\
\hline 110 & 2003 & $\begin{array}{l}78 \text { docs } \\
\text { h-index } 12\end{array}$ & $\begin{array}{l}171 \text { docs } \\
\text { h-index } 18\end{array}$ \\
\hline 111 & 2009 & $\begin{array}{l}42 \text { docs } \\
\text { h-index } 12\end{array}$ & $\begin{array}{l}67 \text { docs } \\
\text { h-index } 18\end{array}$ \\
\hline 112 & 1994 & $\begin{array}{l}44 \text { docs } \\
\text { h-index } 8\end{array}$ & $\begin{array}{l}171 \text { docs } \\
\text { h-index } 24\end{array}$ \\
\hline
\end{tabular}

